\title{
Escrita no ar
}

\section{Karl Erik Schollhammer}

Nesses tempos virtuais, a escrita já procura abandonar a inércia do papel para uma existência mais adequada à necessidade de comunicação imediata. Assim também aconteceu para a "nossa" Escrita, revista produzida pelos alunos de pósgraduação, mestrado e doutorado, cujo papel principal é oferecer aos leitores, os resultados paulatinos, múltiplos e diversificados deste organismo dinâmico que é formado pelo ambiente de quem passa pelas salas de aula, pelos colóquios e seminários, pelos corredores tumultuados da PUC, pelos cafés do Leme e pelas veredas do idílico campus da nossa universidade.

Muito mais que um conjunto de contribuições de autores autóctones, a Escrita é voz plural de muitos focos de leitura e de pesquisas nas línguas, culturas e literaturas lusófonas do passado e da atualidade. Forma parte de uma autoria aberta e dialógica, mestiça, híbrida e ainda sem fronteiras definidas em que autores emergem dentro do conjunto de um catalisador anônimo e criativo definido pelo seu conjunto. Hoje, as condições autorais mudam rapidamente e as trocas de saberes e de escritas são essenciais para a emergência de sentidos. A diversidade criativa deste número de Escrita se reflete nos nomes dos autores trabalhados - Maria Gabriela Llansol, Miltom Hatoum, António Maria Lisboa, Alexandre O’Neill e Herberto Helder - mas a principal riqueza encontramos na liberdade de abordagens e estilos em que estudos de linguagem, de história do livro, de práticas de intervenção social pela literatura, de bibliografia e biografia se misturam com contribuições monográficas mais clássicas, uma entrevista com o escritor português Gastão Cruz e um conto de uma autora recentemente premiada. Assim, muitas linhas de pesquisa são traçadas e entrelaçadas, evidenciando a liberdade disciplinar e a audácia metodológica que cabe dentro do programa de pós-graduação de Letras à procura permanente de inovação de leitura e de novos saberes.

A Revista Escrita é espaço privilegiado para expor a criatividade do nosso programa de pós-graduação, mostrando o que aqui se pensa e produz e expondo-se ao diálogo, à crítica e à intervenção como a única maneira de driblar as opiniões dogmáticas e as verdades estanques. 